\title{
A Radical Agenda for Men's Caregiving
}

\section{Gary Barker*}

\begin{abstract}
The gender equality agenda has long discussed the unequal burden of care work for women and girls. But this debate has seldom focused on how to create the conditions necessary for men and boys to do more care work and be part of a global effort to value care work, regardless of who carries it out. In this analysis of global data and trends, the author argues for a radical shifting of the conversation to understand the resistance to men's care work, the benefits to men of greater participation in care work, and provides a set of policy recommendations for how to promote this change. The article also argues that the benefits of men's caregiving may be the impetus to move from a limited and zero-sum notion of the 'patriarchal dividend' to a 'gender equality dividend' with benefits for women, children and men themselves.
\end{abstract}

\section{Introduction}

At a recent UN expert group meeting on gender equality and post-MDGs, I argued for a global goal of men and boys doing 50 per cent of the world's unpaid care work. This idea was met mostly with two responses: (1) that it is impossible (e.g. that men and boys would never do this, or that we could never change the structures of women's and men's lives to achieve this balance); or (2) that it is a quaint idea but immaterial for achieving gender justice.

This was and is my argument: men and boys doing gender justice and achieving richer and fuller (including healthier and less violent) lives - and women and girls achieving their full potential in political, social and work spheres requires nothing less than a radical redistribution of care work. Far from quaint idea, or a 'feel-good' moment on a greeting card around Father's Day, the politics of men's caregiving must be part of the front line in the still very incomplete gender equality revolution.

To be sure, feminist activists, theorists and researchers have long argued for this radical change, but most of that discussion has centred on how to value - economically and socially - the care work that women and girls provide (see a review of this research in IDRC 2013). Much less of that discussion has focused on how to create the conditions necessary for men and boys to do more care work and be part of a global effort to value care work, regardless of who carries it out.

The advances of the gender equality revolution for women's lives are increasingly clear. In the global South, over the past 30 years, we have effectively achieved educational equality at the primary level. With a few exceptions, girls are studying in equal proportions as boys, at the primary level (World Bank 2012). Some countries in sub-Saharan Africa, Asia and Latin America have achieved, within 20 years, the same declines in fertility and maternal mortality that it took Europe and North America some 100-150 years to achieve (World Bank 2012). These changes mean that more of the world's children are wanted children and that, even in places where fertility has historically been high, there is a gradual but real shift towards valuing the quality of children's lives rather than the quantity of children.

In the recent World Development Report (World Bank 2012, which focused on gender equality) the World Bank affirmed that women are now 40 per cent of the global paid workforce and half of the world's food producers. Women's income has increased relative to that of men although it still lags men with unacceptable pay gaps; according to global data from 2007, women earn 
22 per cent less than men even when they work the same hours as them. At the same time, some groups of women in middle and upper income countries are now earning more on average than their male counterparts. In much of the world, however, we see that gaps between men's and women's income are even higher in higherpaying professions (including politics); it is far less likely that men at these higher income levels are doing an equitable share of care work. ${ }^{1}$

Equally important is what is happening in the social imagination: there is now a generation of boys and girls in many countries who have gone to school together, who may see each other as equals and who have increasingly seen their mothers and other women carry out activities outside the home - in particular, working outside the home and contributing more to household income, and in positions of leadership - that used to be considered the purview of men.

In results from the multi-country household surveys with men - the International Men and Gender Equality Survey (IMAGES), coordinated by Promundo and the International Center for Research on Women and partners - the coauthors found that younger men, men with some years of secondary education, and urban-based men are more likely to 'buy into' and believe in gender equality and to live it or practise it in some aspects of their daily lives (Barker et al. 2011). In other words, on average, young, urbanbased men with some secondary education hold more equitable views than older men, those in rural areas and those with less schooling. Given that the world is becoming more urban, and that young people in much of the world are staying in school for longer, young men are being pushed or increasingly socialised - towards accepting gender equality.

\section{The stickiness of men's practices}

In addition to limited take-up of care work, as noted earlier, looking at men's practices related to violence, we see the stickiness in gender inequality. Global rates of men's reports of lifetime use of physical violence against female partners range from about 20 per cent to more than 70 per cent (García-Moreno et al. 2005). While we lack comparable data over time to measure men's use of violence against women, the data we have suggests that such rates remain persistently high. Most countries have passed laws or policies aimed at reducing this violence and seeking to hold men responsible for such violence, but changes in women's daily, lived experiences of violence from male partners are far too slow in coming. In addition, when asked what they think about these laws as part of IMAGES, the majority across the countries included believed that such laws made it 'too easy' to charge men with having used violence (Barker et al. 2011). This finding suggests both that such laws have disturbed men's sense of entitlement, power and privilege, and the need to change social norms and the institutions that sustain them to end the acceptability of men's use of violence against an intimate partner.

In terms of caregiving in the global South, it is still women and girls who carry out the majority of unpaid domestic and care work (and this includes care of children, the elderly and ill family members) (IDRC 2013). Numerous time use studies from lower- and middle-income countries find that the mean time spent on unpaid care work by women ranges from two to ten times that of men (Budlender 2008; IDRC 2013; and Barker et al. 2011). Data from IMAGES showed that close to half of men who are fathers report spending some time providing care for their children on a daily basis, but their selfreports of time use (and women's reports of their male partners' time use) found that men's time was typically far less than half of women's time spent on the same activities (Barker et al. 2011).

In parts of the Global North, we have seen significant increases in men's participation in caregiving. A recent European-wide review of the data found men doing between 20-40 per cent of the care work as of 2010 (European Union 2013). In spite of these increases, no country in the world has achieved parity in caregiving, nor in women's income relative to men. Even

Scandinavian countries, which for nearly 20 years have used paternity leave and other policies to encourage men's caregiving, have not achieved parity in men's and women's income and caregiving. In addition, men's uptake of family leave in Scandinavia and a few other Global North countries has increased steadily but is still not on a par with women's uptake of maternity leave (European Union 2013).

Furthermore, an attitude survey conducted in 23 European countries found that women frequently reduce their working hours to part-time when 
they have children (International Social Survey Programme 2004). Across the countries surveyed, 50-70 per cent of respondents agreed that a woman with a child of school age should work part-time. Other research affirms that women are more likely to make long-term, radical changes in their professional lives as a response to having children, generally working part-time or by changing assignments to cope better with the needs of children and family life. Men, in contrast, often maintain their full-time employment, take only short periods of parental leave or temporary cash benefits and concentrate instead on temporary efforts to solve the problems that arise between work and family life (Plantin 2007). On aggregate, in the global South and North, the norm in the context of heterosexual couples with children is that women are still expected to take time off from work to care for children more than men are.

\section{Why the division of care work matters}

With all the other pressing issues in gender justice and social justice, why does caregiving matter? First and foremost, men's lagging participation in care work serves to keep women's wages lower than men's (which in turn is translated into less participation and power inequalities in social and political spheres). It also, as we have seen in study after study, shapes gender regimes, systems of childrearing, cycles of violence and cycles of poverty.

Research on the effects of men's participation in families fills volumes (for an extensive review, see UN Department of Economic and Social Affairs 2011). Children in households with more equitable participation of men show better health and development. Women raised in households with more equitable fathers or other adult male caregivers show lower rates of experiencing unwanted sex. Men who report stronger connections to their children tend to contribute more of their income to their households. Data from Sweden shows that households where men share the care work show higher income for women and for the household overall (Plantin 2007). Women report greater life, sexual and relationship satisfaction when male partners are more involved in care work (Barker et al. 2011). Women whose partners are more involved in pre-natal visits and in childbirth report calmer, more secure childbirth experiences (see for example, Carter 2002).
The benefits to men themselves are also clear. Men who report stronger connections with their children show better health and mental health, lower rates of substance use, and lower rates of incarceration (see for example Bartlett 2004). Clearly causality is multiple and probably bidirectional in all of these associations but there are consistent benefits found in studies from around the world when men (with children) participate more and in non-violent ways in the lives of their children.

\section{The IMAGES study also revealed the} intergenerational effects of men's participation in caregiving: men who saw their own fathers or other men in the household carry out caregiving and demonstrate gender-equitable behaviours were more likely to do care work and have equitable attitudes as adults (Barker et al. 2011). In other words, caregiving by men is a 'gender equality dividend' that pays forward in multiple ways.

Researchers and theorists have long discussed the 'patriarchal dividend,' which is the notion that all men accrue some benefits, tangible or otherwise, as men in a patriarchal world (Connell 2005). This notion of a gender equality dividend suggests that there may be some areas or domains, particularly caregiving, in which, if shared equally, there are benefits for women, children and men. In other words, there may be some areas of gender relations in which it may be possible to think beyond a zero-sum approach.

All of these effects are at the individual or family level. What of societies? Some feminist scholars have long argued that men's distance from caregiving is associated with the fact that violence of nearly all forms - homicide and war in particular - are more likely to be men's violence. Conversely, Valerie Hudson (2012) argues that countries with greater gender equality (which includes men's participation in caregiving) are less likely to have experienced conflict. Clearly conflict, war and homicide are much more complex and multi-causal than gender equality and men's caregiving. But early life experiences and persistent structures that separate boys and men from the daily care of others serve to construct men, masculinities and gender regimes that, together with other factors, perpetuate men's violence and propensity to violence, whether in conflict, war or interpersonal relations. 
Caregiving is empathy, responsibility and emotional connection in daily practice. To be disconnected from caregiving is to plant the seeds for emotionally detached boys and men who see caregiving as secondary and exclusively feminine. It feeds and sustains views of manhood as synonymous with being providers and protectors, and as superior to all things feminine. And it too often feeds into the view that the production of goods and income is always and inherently more important than the creation of solidarity, reciprocity and meaningful social connection with others. It creates men and boys who show limited care for their own bodies and the bodies and bodily needs of others.

The separation of men and boys from caregiving also inhibits the healing and rebuilding in countries affected by conflict. A recent application of the IMAGES study in Eastern DRC shows how women show greater and more positive coping with the multiple insidious effects of conflict by going on with the daily work of caregiving and by their reciprocal relationships with other women (Slegh et al. 2012). Men in this study show higher rates of having thought about suicide and more depression than women, and were far less likely to seek help or provide help.

\section{Studying the lives of men who care}

As a complement to the multi-country IMAGES household survey mentioned earlier, we interviewed 83 men in five countries in life history interviews (Barker et al. 2012). The men were selected because of their atypical caregiving activities. They were the primary caregivers of children or of an elderly or ill partner or parent, or they were involved in caregiving professions that were atypical for men in their context (as care workers, primary school teachers, nurses or gender equality activists). While each story was unique (and each context unique) there were striking similarities. For example, the 'men who care' frequently reported resistance from their families and female partners (for those in heterosexual relationships) to their roles as caregivers, either in the home or as professions.

They also consistently reported that they took on their atypical caregiving practices because of life circumstances. Nearly all of the men said that they took on this caregiving role because of external forces, not because of some greaterthan-average belief in gender equality. These life circumstances included the death or illness of a partner, the higher income or employment situation of a partner, unemployment on their part or the mere happenstance of finding a certain job. For most of the men interviewed, gender-equitable attitudes did not lead them to do more care work. Rather, the practice of doing care work, thrust upon them by life circumstances, led them to have more genderequitable attitudes.

Many of the 'men who care' reported that doing care work gave them new insights into women's and girls' lived experiences, or those oppressed by homophobia. They also said it opened up new avenues and perceptions for connecting to others (male friends, other family members, female or male intimate partners) in relationships of greater emotional honesty and empathy. In sum, they said it made their lives richer, while it fulfilled an important need in their family or household life.

At the same time, the 'men who care' consistently reported feeling isolated and depressed in their caregiving practices. Many were worried that their children would not see them as 'real men' if they were not also working outside the home in some paid work or profession. Their narratives in many ways resemble those of women talking about their care work. The discourses of the 'men who care' affirmed an acute awareness that their social networks and society in general do not value care work whether carried out by women or men. Indeed, valuing the care economy and taking it to be as serious as any other joint human endeavour would both acknowledge and empower the women and girls who at present provide most of it, and it would encourage men and boys to carry out more of it - with benefits for all of us. It would generate more of the gender equality dividend.

\section{Some directions for a care work revolution}

We know, of course, what societies and mainstream social institutions generally value in men (and increasingly in some settings, in women): performance; the accumulation of capital; manhood based on conquest; and the individual (man) who invents or creates, and who is autonomous and self-sufficient. While these traits may have once been mostly promoted as a Western liberal or neoliberal idea, they have been, in many ways, globalised and marketed to much of the world. In general we value the heroic 
inventor of a computer application, the winner of a grants competition or the successful businessperson. We too seldom inquire how care work fits into this Western, hegemonic view of the provider man (and woman in some workplaces, professions and settings), or when we do, the caregiving is considered of secondary importance. Again, causality is multiple, but our perpetuation of a hegemonic masculinity based primarily on production is associated with a model of capitalism that is materialistic and short-term and shows limited concern for sustaining families, individuals or the environment.

With the gender division of caregiving so deeply and historically ingrained or entrenched in our social institutions, how do we realistically achieve meaningful changes? We know that media or community campaigns, however important those can be, are not enough. Social norms must shift. But the heart of the revolution is around the meanings and markers of manhood - particularly as those are shaped in the policies, workplaces, institutional and community structures. Hence our work must be about changing these structures.

Indeed, our work with men and boys must evolve beyond our laudable but short-term programme goals of increasing condom use, or reducing violence, or increasing hours devoted to care work, to this structural level. While far from complete, some of these recommendations include:

- Equal, non-transferable and paid parental leave;

- State- or workplace-supported childcare and family care;

- National policies to increase men's participation in reproductive and sexual health so that 50 per cent of contraceptive use happens via men's bodies; ${ }^{2}$

\section{Notes}

* Special thanks to Michael Kaufman, Jane Kato-Wallace, Dean Peacock, Nikki Van Der Gaag, Wessel Van Den Berg, Niobe Way and all the co-authors of the IMAGES and the Men Who Care studies for their various contributions to ideas presented here.

1 These conclusions and trends are all taken from the 2012 World Development Report.

2 A much longer discussion is needed about the connection between men's caregiving and
- Making caregiving part of the school curriculum for boys and girls, and equally;

- Equality of supports, governmental benefits and societal respect for all caregiving arrangements, including same-sex parents and adoption of children by lesbian, gay, bisexual, transgender/transexual and intersexed (LGBTI) individuals;

- Incentives to encourage workplaces to offer flexible work time and adequate family leave;

- Income support policies that encourage men's participation in family life and as caregivers (breaking assumptions that men do not care or will not contribute income to households).

These are precisely the policies, along with others, that need to be considered globally taking into account specific country contexts - if we are to take seriously full equality in care work. They should be complemented by and at times follow the lead of key NGOs that are experimenting at the community level to achieve changes in men's caregiving. ${ }^{3}$

Engaging men in caregiving cannot be reduced to only measuring men's time use or to making men feel good around Father's Day for things they should already be doing. It is nothing less than a fundamental reworking of our work-life balance and our beliefs in the purpose of our lives and relationships. As a global community, we are coming upon the moment of negotiating the new global development goals. As we do so, we must focus on the policies and micro- and macro-level structures and institutional practices that encourage or inhibit equality in caregiving. Indeed, it is precisely this debate and discussion that will determine if we will evolve towards being a more caring society or a 'care-less' society.

their participation in contraceptive use and sexual and reproductive health in general. We could argue that men who are more connected to children they already have or involved in care work of multiple forms are more likely to be active in decision-making about contraceptive use (in the context of heterosexual couples).

3 For examples of some of these, see www.men-care.org. 


\section{References}

Barker, G.; Contreras, J.M.; Heilman, B.; Singh, A.K.; Verma, R.K. and Nascimento, M. (2011) Evolving Men: Initial Results from the International Men and Gender Equality Survey (IMAGES), Washington DC: International Center for Research on Women (ICRW) and Rio de Janeiro: Instituto Promundo

Barker, G.; Greene, M.; Goldstein, E.;

Nascimento, M.; Segundo, M.; Ricardo, C., et al. (2010) What Men Have To Do With It: Public Policies to Promote Gender Equality, Washington DC: International Center for Research on Women and Instituto Promundo

Barker, G.; Greene, M.; Nascimento, M.; Segundo, M.; Ricardo, C.; Taylor, A.; Aguayo, F.; Sadler, M.; Das, A.; Singh, S.; Figueroa, J.G.; Franzoni, J.; Flores, N.; Jewkes, R.; Morrell, R. and Kato, J. (2012) Men Who Care: A MultiCountry Qualitative Study of Men in NonTraditional Caregiving Roles, Washington DC: International Center for Research on Women (ICRW) and Rio de Janeiro: Instituto Promundo

Bartlett, E. (2004) 'The Effects of Fatherhood on the Health of Men: A Review of the Literature', Journal of Men's Health and Gender 1.2-3: 159-69

Budlender, D. (2008) The Statistical Evidence on Care and Non-Care Work across Six Countries, Gender and Development Programme Paper 4, Geneva: United Nations Research Institute for Social Development

Carter, M. (2002) 'Husbands and Maternal Health Matters in Rural Guatemala: Wives' Reports on their Spouses' Involvement in Pregnancy and Birth', Social Science and Medicine 55.3: 437-50

Connell, Raewyn (1995, 2nd edition 2005) Masculinities, Cambridge: Polity Press; Sydney: Allen \& Unwin; Berkeley: University of California Press
European Union (2013) The Role of Men in Gender Equality: European Strategies and Insights, Luxembourg: Directorate-General for Justice, Office of the European Union

García-Moreno, C.; Janse, H.; Ellsberg, M.; Heise, L. and Watts, C. (2005) WHO MultiCountry Study on Women's Health and Domestic Violence against Women: Initial Results on Prevalence, Health Outcomes and Women's Responses, Geneva: World Health Organization Hudson, Valerie (2012) Sex and World Peace, New York: Columbia University Press

IDRC (2013) Women's Economic Empowerment and the Care Economy: A Scoping Study of the Literature, Ottawa: International Development Research Centre, UK Aid, William and Flora Hewlett Foundation

International Social Survey Programme (GEIS) (2004) Family and Changing Gender Roles III (34 Countries), Z A Study 3880, ISSP 2002, Cologne, Germany: Zentralarchiv fuer Empirische Social forschung, UK Data Archive 5018

Plantin, L. (2007) Fatherhood and Health Outcomes: The Case of Europe, Copenhagen: World Health Organization

Slegh, H.; Barker, G.; Ruratotoye, B. and Shand, T. (2012) Gender Relations, Sexual Violence and the Effects of Conflict on Women and Men in North Kivu, Eastern Democratic Republic of Congo: Preliminary Results of the International Men and Gender Equality Survey (IMAGES), Cape Town and Washington DC: Sonke Gender Justice Network and Promundo-US

United Nations Department of Economic and Social Affairs (2011) Men in Families and Family Policy in a Changing World, New York: United Nations

World Bank (2012) Gender Equality and Development, Washington DC: World Bank 